\title{
The Impact of the Religious Dimension as Building, Urban Fabric and the Social Behavior of the Population
}

- Study Status: City Wade M'zab Ghardaia -

\author{
M. SAOUANE Mohamed Boudiafe ${ }^{1}$, Mme .ZEGHICHI Sarra1 \\ ${ }^{1}$ Architecture Department, Faculty of Science \& Technology, Tebessa University, Algeria.
}

Email: saouanemohamed@yahoo.com

\begin{abstract}
I knew architecture grew since the ages of prehistoric and was the goal of the appearance of architecture at first in order to meet the need and protection from surrounding risks, but with the evolution of architecture through the ages, and the concept of civilization that appeared with the development of architecture gave a special identity to architecture. like Mesopotamia in Iraqi architecture, Egyptian architecture shows African, Romanian Greek, and Islamic architecture. The Byzantine Empire which covered most regions of the world saw the emergence of a very Christian architecture in Italy and the Vatican Gothic factor was the development of this architecture. Prothera next to the religious and ideological thought and philosophy closer to the god of, this architecture was thought the mainstream has actually contributed to the development of architecture during the ages.

In this study, we will study the Islamic building in the North Africa region, which spread in the 10th century and was founded by The Abadites who were Kharijites and spread in the north of the Algerian desert, specifically in the city of Ghardaia in Wadi M'zab. $550 \mathrm{~km}$ from Algiers. This city is designed for social life, and this city is an inspiration for urban planners today. This city has been described in the Book of Lights Mazab of the French Orientalist where he said that her charm attracts visitors to it in one of the pages of this book.

This architecture was characterized by: an inherent system of architecture, a mixture of practical creativity, which was characterized by steadfastness so as to stay adapted and adapted to the difficult climate and nature of the region, and the maintenance of the neighborhood rights supported by a arsenal of ethical systems and customs expressed in the harem. Both inside the palace or at specific distances outside their walls ... Which is covered by a beautiful aesthetic touch and an almost unique architectural feature.
\end{abstract}

Through this study we will explain how They were affected of the building and the urban fabric of the area and the inhabitants of Wadi M'zab affected the religious dimension, how did urban fabric Wade M'zab preserve his building authenticity in terms of the form and mix of art and creativity that appears in urban and Wadi M'zab.

(C) 2019 The Authors. Published by IEREK press. This is an open access article under the CC BY license (https://creativecommons.org/licenses/by/4.0/).

\section{Keywords}

Architecture; Civilization; Evolution; Desert; Beni M'zab; Ghardaia; Islamic Architecture; Desert Architecture; Form of Creativity; Art; Influenced Sanctity; Religious; Religious Dimension 


\section{Introduction:}

The area of Mazab is characterized by its rocky, high-temperature nature, penetrated by a network of wadis where water is only used once a year and sometimes once in a few years, but the conditions have forced men to inhabit the area since ancient times; he tried to find ways to survive and adapt to the environment what he wanted to create a unique urban civilization

Al Omran is a mirror of society and an expression of its behavior and lifestyle. Therefore, Ibn Khaldun and many thinkers have been associated with the words of architecture and civilization. The human civilization does not proceed from the vacuum. Rather, it emanates from an internalized source that is refined by the society from the laws of life inspired by the guidance of God. In its environment of air and dust... Until the necessary conditions for a human meeting are met.

The Musabian society planned its city and its facilities to meet the requirements of its faith and its environment in a collective thought in response to collective demands. Its architecture was characterized by harmony and harmony between its forms and contents. It became a unique model, such as any model, to respond to this harmony between man and the environment and focused on the rules and constants of the city.

The archaeological and engineering reading reveals the extent of man's skill in balancing the biosphere, where the need for soil, the small agricultural land, and the desert palace, which gathers within its walls a population group whose population should not exceed the potential of agricultural space, To search for an agricultural area that is sufficient to satisfy its needs.

This is how the residents of Mazab began to talk with nature until they were captivated by their secrets. In a short period of time, there may be several desert palaces along distances that are well thought out and in keeping with the corresponding land of agriculture. This is despite the simple census that can be confined to one palace. The domain for later generations was behind this plan in urbanization.

\section{Research problem:}

- How the Religious Dimension Affects the Urban Fabric and building of Lwad M'zab Ghardaia?

- How Wade Mzab preserved architecture and what is the secret of its beauty?

\section{Description of the study area}

\subsection{Location of Ghardaia city:}

The, city of Ghardaïa is a city, and a municipality affiliated to the province of Ghardaïa located in the Algerian state of Ghardaïa, located in the north of the Algerian desert and the seat of this state is about $600 \mathrm{~km}$ south of the capital Algiers, its area is about $86105 \mathrm{~km}$, bordered north by the states of Djelfa, Laghouat and Bayadh. On the western side, it is bordered by the state of Adrar, to the east by the state of Ouargla, and to the south by the state of Tamanrasset.

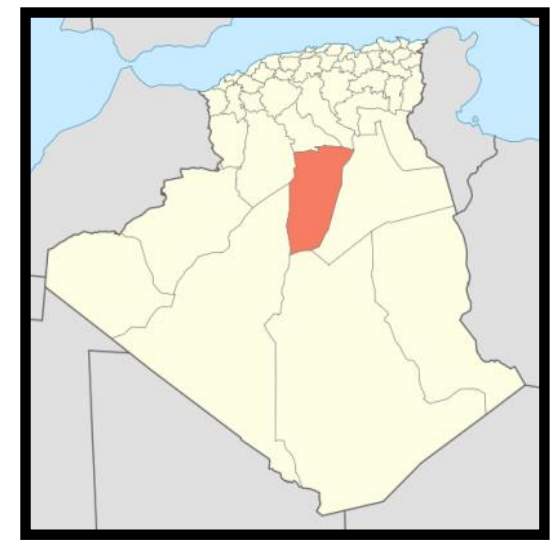

Figure 1. Map of Ghardaïa for the state of Algeria : Source: Google img March2019 
It is about $200 \mathrm{~km}$ away from the capital of the state of Laghouat, $200 \mathrm{~km}$ away from the capital of the state of Ouargla, and about $480 \mathrm{~km}$ away from the capital of the state of Adrar, and it's separated from the capital of the state of Tamanrasset by $1200 \mathrm{~km}$. The national road number 1, which connects the Algerian capital to the captivating big south, cross this city.

\subsection{History of the city of Waz Mzab Ghardaia:}

In the past Ghardaïa was a part of a valley called Mzab. It was one of the villages that had been attacked by the Fatimids during their reign, but its residents could build castles to protect it from the invasion. In the eleventh century $\mathrm{AD}$, many people emigrated to it to escape the wars that were going on then, because of its safety. In the twelfth century AD, the Arabs inhabited it, people of Al-Mansur and a group of tribes such as Al-Shurafa, Abdul Qader and others. In 1679, there was a conflict between the Arabs, and the barbarians who tried to obtain it in order to expand their areas of rule, but the original habitants could protect it which contributed to its transformation from a small village to a large city. But in 1864 it was subjected to French occupation, the people of Ghardaïa made a revolution against the French and they managed to liberate it and preserve their cultural heritage ${ }^{12}$.

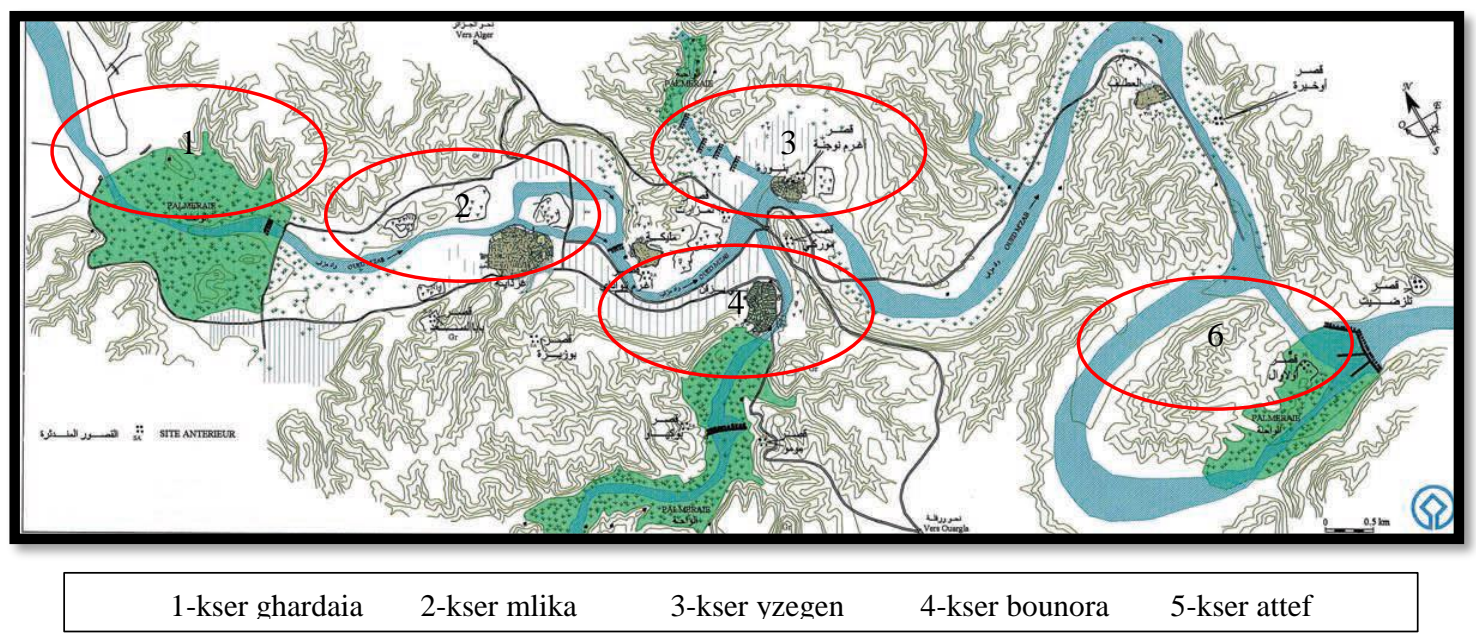

Figure 2. The Map: represent the location of the Wad Mezab ksore in the city of Ghardaiasat.

Source: Office of Protection and Promotion of the M'zab Valley

\subsection{The population of Wadi Mzab Ghardaia}

The inhabiting of this region extends to thousands of years and is evidenced by the barbarian inscriptions on the rocks which date to 3000 years $\mathrm{BC}$, and it has witnessed the rise of many villages of the Amazigh tribes known as at. Mzab

The demographic growth of the region also developed after the fall of the Rust mite state and the destruction of the city Secretary. The inhabitants embraced the moderate Ibadi doctrine which added a scientific revival to the region.

The region witnessed the immigration of nomad of the Arab tribes of the Maliki school due to deceases, these were Al-Mazabih, Beni Merzouq, Al-Shaamba who came from the Wahrani sector and various parts of the Algerian Sahara and who lived a Bedoui life. Then most of them settled in the palace of Metlili, and in the seventeenth century AD, some of them left to establish the city of Menia, they were called Shaamba and those who stayed in Metlili were called Shaamba Berzga ${ }^{3}$.

\subsection{The climate of Wadi Mzab Ghardaia:}

The location of the city in the desert has led to the prevailing of a dry climate with the lowest temperature in the winter as 1 degree Celsius while the highest one is 25 degrees, Celsius. While in the summer, the lowest

\footnotetext{
${ }^{1}$ A . Mohamed A. AlWahab. (2012) Specificities of desert urbanism

${ }^{2}$ Benyoucef . B.(1992) The problem of urbanism and the Islamic project, Alger, Abu Dawood.

${ }^{3}$ Benyoucef . B.(1992) The problem of urbanism and the Islamic project, Alger, Abu Dawood.
} 
temperature is 18 degrees Celsius and rises to the highest level of 48 degrees Celsius, with mild weather in the spring and autumn and a clear sky most days of the year. The levels of rainfall are about $60 \mathrm{~mm}$ per year, most of them during the winter. The latter also witnesses north-westerly winds which cause cold weather. Spring is dominated by the sandy southwest winds, while the summer ones are called Sirocco, blow from the south and are usually hot.

\section{Analysis of the results of the study area description:}

\subsection{How the Religious Dimension Affects the Urban Fabric and building of Lwad M'zab Ghardaia:}

Since its establishment, the palaces of Mezab have maintained the same architectural style for more than ten centuries. They have largely harmonized the intellectual system of the community with the natural environment in which it lives. Urban architecture is an expression of its behavior and lifestyle. Therefore, Ibn Khaldun and many The human civilization does not start from the vacuum, but rather from an innate internal source that is refined by the society from its laws of life, inspired by the guidance of God, and by its long experience, combined with the elements of life in its environment of air and dust. I necessary for human meeting.

\section{- Creating the urban area:}

The creation of the field: The community of Mzabi planned his city and its facilities to meet the requirements of his faith, and his environment in a collective thought from collective demands. His architecture was harmonious and concordant between its forms and contents. The social and religious dimension has a great affect the structure of the mausoleum palace. First, the agreement is to agree on its borders, its benefit's sites, and the dimensions and dimensions of its methods. The agreement is a basis of the Ibadi social foundations, which derive its strength from the principles and values of Islam. The spatial and spatial distribution of the palace governs five pairs that reflect the social dimensions of the Mesopotamian society ${ }^{4}$.

- The most important Islamic principles of the Abadi society which influenced the urban fabric and buildings:

\subsubsection{Internal and External:}

Internal and external: The internal the individual is the entire palace and not only his home, and society and his family and the individual responsible and guarded from society and the house of society in all necessary, and the community responsible for the individual being a member of the family, while the outside is an outsider on the palace and the community adds it is ignorance.

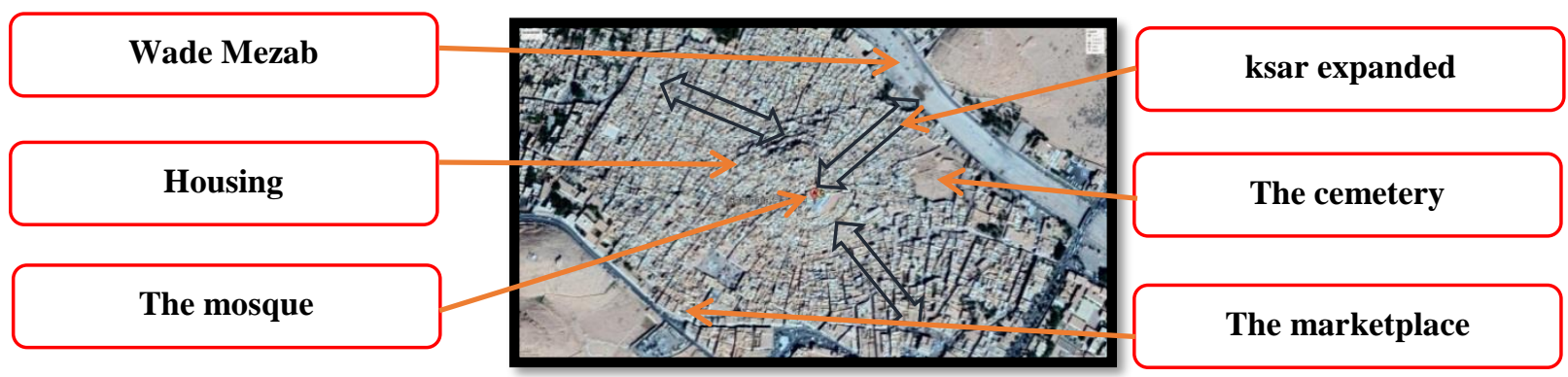

Figure 3. The structural elements of ksore and the valley of M'zab Ghardaia. Source: Google Earth March 2019.

\subsubsection{General and Private:}

And the communities of that community, the palace is divided into neighborhoods by tribes and clans, and the neighborhood area of the tribe or the tribe inhabited by the roads and is divided into a general community and

\footnotetext{
${ }^{4}$ Wikipedia .(2011) All you need to know about Ghardaiahttps://ar.wikipedia.org/ wiki/ Ghardaia.

${ }^{4} \mathrm{Al}$ - Fustai S . Abu Abbas. A. (1997) Division and the origins of the two lands. (2nd ed.) Grara,Ghardaia Inquiry. Zahra forArab Media
} 
secondary and secondary to the people of the neighborhood, and is divided into a general and non - but the market is a public space reserved for men without women, boys and youth, so that the mosque remains a space for all members of society to their race and age and is divided into two areas according to gender.

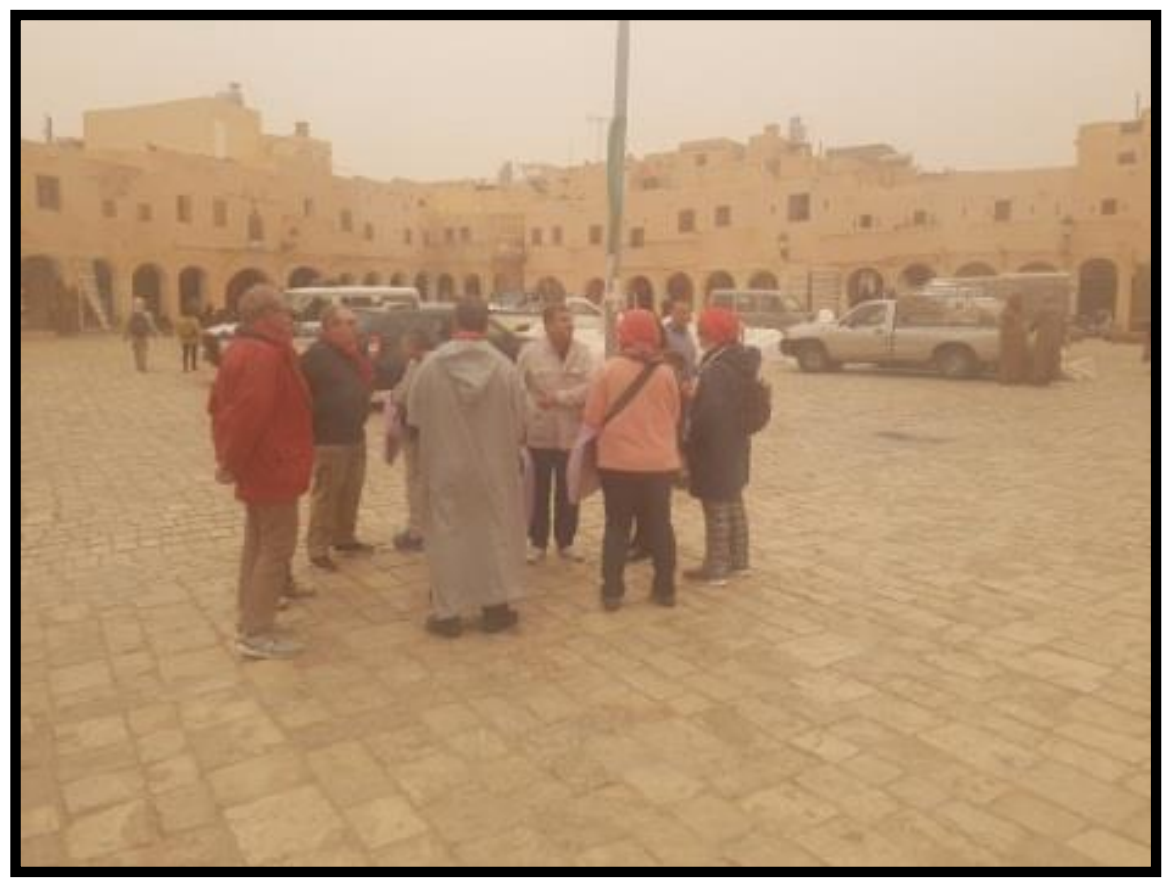

Figure 4. Photo The marketplace. Source: researcher March, 2019

\subsubsection{Life and Religion}

As religion has supreme status and supervision and what is the worldly lower and lower rank of the Muslim individual and the committed community, the religious and secular cities in the Mzab palaces have received the same position, we find the mosque occupies the high position in the city, where the center of life and the authority of the Islamic community, and on the other hand, we find that the market and that place is placed under the palace, but that does not mean a break. In addition to this part, the market on the door of the palace to allow the stranger to spend its results without penetrating that palace, in the market is digging a well to water the convoys and the needy.

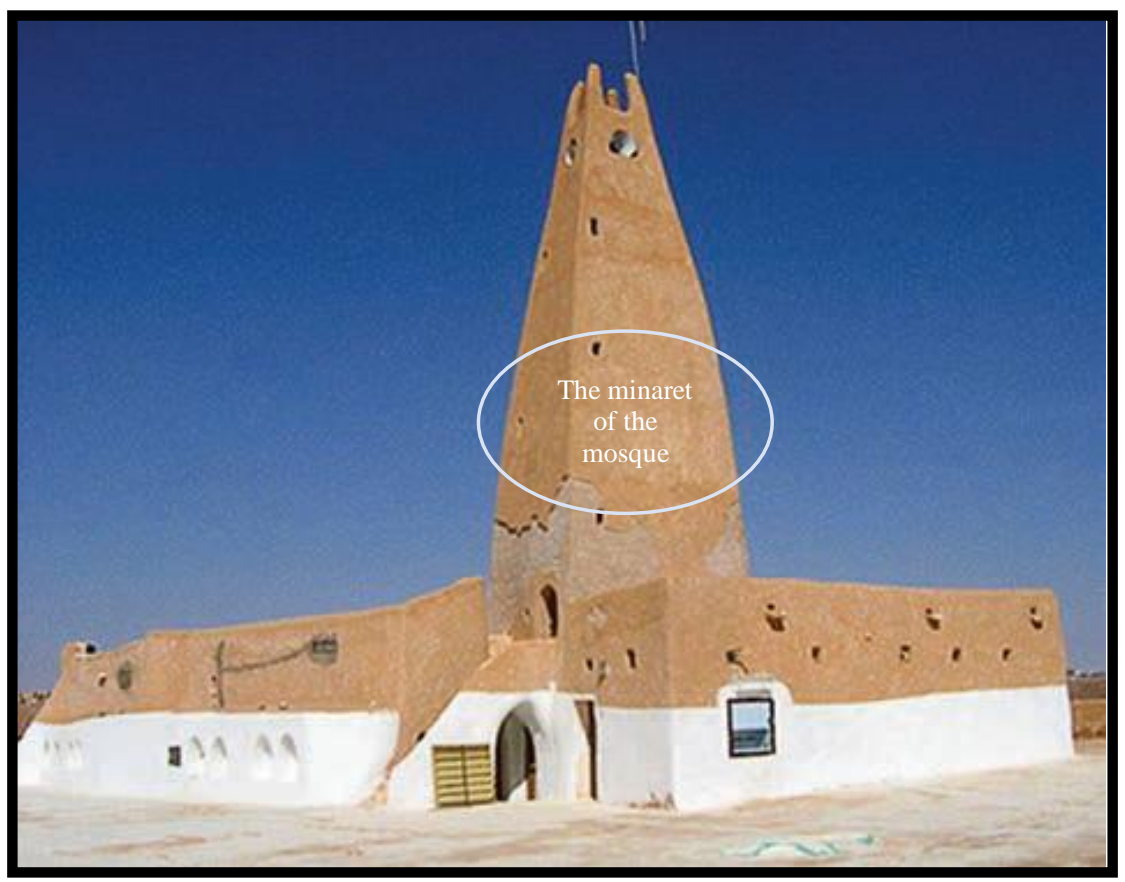

Figure 5. The image of the mosque is located at the top of ks. Source: researcher March, 2019 


\subsubsection{Living and Dead:}

The palace represents the active and vibrant place while the tombs outside the palace next to its entrance, which show the lack of life, and absent all the symbols of the distinction between the grave, and the other to equate people

The palace represents the active and vibrant place while the tombs outside the palace next to its entrance, which show the lack of life, and absent all the symbols of the distinction between the grave, and the other to equate people living conditions equal to the building and equal dead as the teeth of the comb, except some signs that are raised beside the graves of scientists for them because the balance of differentiation when God piety. He mentions the outside of the palace with his fate, so he does not miss the world 5 .

\subsubsection{Men and Women:}

The human society consists of men and women and the relationship between them relates to the marital relationship or family relationship. The man has to provide care because he is responsible for the family, while women have to raise and raise children. In order to organize the lives of both sexes within society, between men and women according to their needs. The market is the space of men excellence, while the remaining parts of the minors from the houses and alleys is a space for women first class, the private housing space, which is engaged in normal activities and use the alleys to communicate and cooperation between them in the mosques and others, although they communicate across the roofs most often, and children if they are not playing at home The alley is near the houses, which are often open, under the supervision of the mothers, whereas the men do not use the alleys of the lemur. It is not allowed to open a shop or shop outside the Market square ${ }^{6}$.

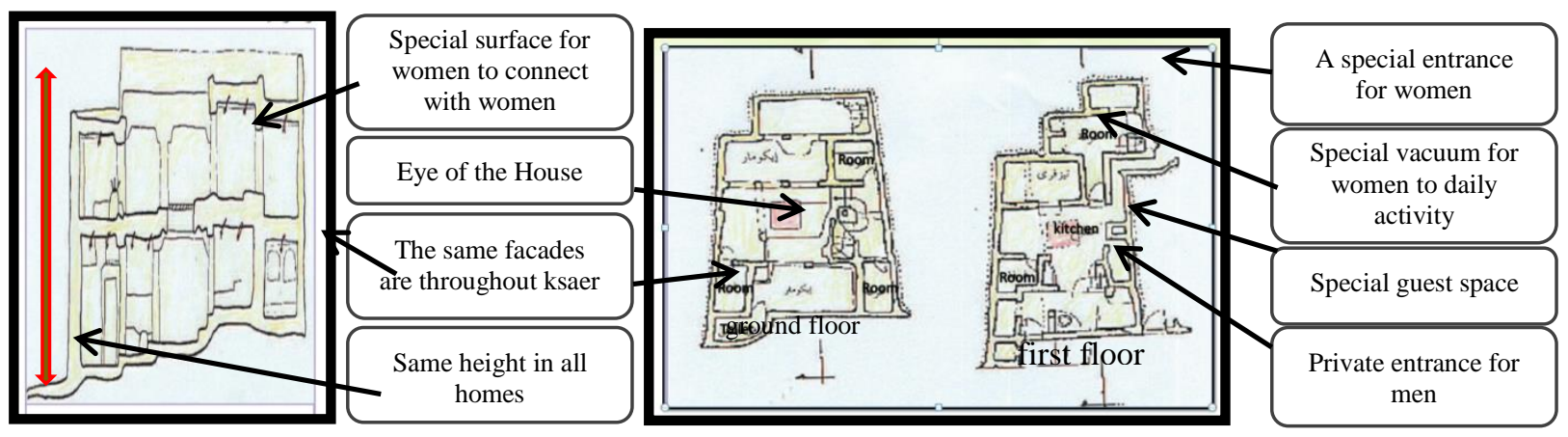

Figure 6. Plan for the traditional residence of Ghardaia kaser. Source: Office of Protection and Promotion of the M'zab Valley 2019

Considering the five colleges and it can be limited to the models of them are as follows: Structuring of construction: it is customary in construction there is a certain rise that does not exceed it. The structure of the building: it has become customary in the construction that there is a certain, taking into account the five colleges and can be limited to models of them are as follows:

\section{Structuring of construction:}

It is customary in construction there is a certain rise does not exceed it, where not allowed more than one floor above the ground floor. The height of the floor is estimated to be as high as that of the human being Especially women who work at home, and the source of the sun is the upper surface nets in this conservation of the soul. And the rise on the neighbor is looking forward to and revealed to conceal, which restricts the movement of the neighbor and the bottom of the house inside this customary procedure is a preservation of the symptoms; and because people distinguish instinctively in the capacity can be any building as he wanted, but this encroachment in the structure has revived the Sharia and the Prophet, The Mzabi architecture is characterized by rationality and provide the need for perfection and useless increase paid by the owner of projects, especially private or public profit for the latter and in this feature save for money. ${ }^{7}$

\footnotetext{
${ }^{5}$ Hadj M. Ibrahim.(2015) Urbanism in Mzab and the Art of Creating the Biosphere (Social Norms and Urban Implications) P 200

${ }^{6}$ Hadj M. Ibrahim.(2015) Urbanism in Mzab and the Art of Creating the Biosphere (Social Norms and Urban Implications) P 202. 203

7 The same reference mentioned above
} 
To avoid long exposure to the sun in the east-west direction. The measurements of the nature of the work and ease of passage through the foot of the foot 3 arms, watering, and firewood 5 arms, • (camel road 12 cubits, donkeys 7 , bearings, grazing roads and pilgrims 40 arm As well as the height of the stairs, which does not exceed the height of the human heel and animal hoof. The door openings are taken to be the entrance to the house and have certain measurements where the lower thresholds are high by about $20 \mathrm{~cm}$ to prevent the leakage of rain water flowing through the streets or cold air in winter, and prevent the entry of reptiles and insects; and the height is large long to block the hot air in summer, but there is an increase in supply to enable the animals loaded with supplies and water easily enter the center of the house, To the street, but to the inside so as not to obstruct the passage of the legs or the animals. The windows do not take to the street, but they take small fans for ventilation because they do not encroach upon the neighbors' sanctities. The sound of the rooms is not heard in the street, and the window of the roof is open enough for a generous share of the sun and air.

\section{Selection of building materials:}

Masons in their children relied on local materials extracted from the direct natural environment and are available In addition, the palm trees in the oases are planted with stems and leaves to raise and roof the houses and make the doors. The use of these natural materials has been beneficial to the community to respect and appreciate it as a blessing provided by God to serve his slaves, and must honor them not waste them and provide them in what works.

\subsection{How Wade Mzab preserved architecture and what is the secret of its beauty?}

-Secrets of the aesthetic architecture in the desert palaces Musab:

\subsubsection{Harmony with the Universe:}

Urbanism is unique to any model that is particularly consistent in other areas, so that the group interested in urban planning is asked again, philosophically and deep about the background and social imagination that coordinated this area. The urbanization of Mazab is characterized by a special taste and a special aesthetic touch, which has been spontaneously embellished and created by Divine Providence in the hands of a society which has guided the values of Islam and the religion of instinct. This harmony is manifested in an exquisite form in which a person feels his presence in his earthly nature, and his instinct that does not seek the cost. The five in the religion as a custom of due diligence during Construction and single engineer: the collective spirit and volunteer work carried out Construction and the One Engineer: On the collective spirit and voluntary work, the civilization of the Wadi Mzab and its citizens became its citizens. When the palace was built over time, the work was based on the principles of the community and volunteering. As owners or owners of houses want to build their house, aid is needed, and it can call the people of the palace and its neighbors to assist in transporting construction materials or roofing or lifting walls. The mosque follows the prayer with its need and sets the date and finds the white hand in its job. The same volunteers (i.e., the people of the palace) mean another and so that the accomplishment of the palace is like the achievement of one man. And this volunteer spontaneity totals the obligation not to stand with the neighbor, even if not with him on the horizon will be deprived will go to volunteer construction, the neighbor in the orchard will water your garden on your behalf and spontaneously. This general appearance of the palace at the level of much of harmony. The neighbor in the orchard will water your garden on your behalf and spontaneously. This general appearance of the palace at the level of much of harmony.

\subsubsection{Unity and diversity:}

Although the architecture of Wadi Mzab represents a unit and a homogeneous mass element and components so that it sees equality and similarity between all the houses and between the various facilities and facilities from the house to the mosque so as to reflect the unity of purpose and unity of society, but in this unit richness in polymorphism and landscape So that each dwelling of each space and each area is a harmonious unit not repeated in a building or elsewhere; it is not subject to rigid molds in style or shape, but it was a conscious response to the needs and necessities that dictated Response to requirements: The urbanization of Mazab was not built on complexity. All that is visible to the beholder is a response to necessities Society and its innate needs and a direct 
reflection of the way of life and the nature of activities. Any part of the building is to hurt a particular function or to symbolize a goal.

\section{Research Results:}

The early builders of their engineering in the valley of Moab were in Islamic rules and rules inspired by Islamic law, which they agreed upon.

The care and cooperation between the residents of Wadi Mzab and the foundations of the establishment of this civilization. -The Mezab Valley, region is considered a sustainable city, considering the social, economic and environmental aspects.

Wade Mezab is a UNESCO protected area. -Residents of the area were able to emit all the primary resources in the area and use them in construction. -Despite the desert environment, the man was able to overcome these difficulties through design.

Development of water distribution system and use of flood water. -Responding to community requirements contributed to the appearance of this architecture. -The selection of Wad Mzab high plateaus to protect against wars. Respect for women and respect for their sanctity during the design of the palace to provide spaces for daily activity and continue with the rest of women.

\section{References}

Al - Fustai S . Abu Abbas. A. (1997) Division and the origins of the two lands. (2nd ed.) Grara ,Ghardaia Inquiry. Zahra forArab Media

A . Mohamed A. AlWahab. (2012) Specificities of desert urbanism (Master Thesis.) University of Laghouat. Algeria.

Benyoucef . B.(1992) The problem of urbanism and the Islamic project, Alger, Abu Dawood.

Khalid .A .(2013) Legitimate politics and jurisprudence of architecture, boundaries and common Alexandria Al-Sharq Al-Awsat Newspaper, Issue 12769-13 November2013

Hadj M. Ibrahim.(2015) Urbanism in Mzab and the Art of Creating the Biosphere (Social Norms and Urban Implications) number 22 Special 2015 SSH. ISSN: 2170-1121 .http://dspace.univ- jouargla.dz/jspui/handle/123456789/10262

Mohammed A.Sattar Othman, (1988). Islamic City, World of Knowledge Serie s(NA.) .Kuwait, National Council for Culture, Arts and Letters.

Ramadan. K \& Hamo A. B (2013) Custom in traditional Mzab Valley construction, (1nd ed.) Ghardaia. Office of Protection and Peromation of the M'zab Valley.

Yousef. B .Bakir H. Saeed (1991) History of Beni Mzab, Ghardaia, Arabic Printing Press(2006)

Wikipedia .(2011) All you need to know about Ghardaiahttps://ar.wikipedia.org/ wiki/ Ghardaia.

Office of Protection and Peromation of the M'zab Valley. (2013) .http://www.opvm.dz/.

André Ravéreau. (1981). Le Mzab une leçon d'architecture. (04/03/2003) SINDBAD. ISBN : 2742742700 